\title{
Authentication Using Volatile Composition: A Proof-of-Concept Study on the Volatile Profiles of Fourteen Queensland Ciders
}

\author{
Arron Wilson ${ }^{1}$, Joel B. Johnson ${ }^{1,2}{ }^{(-)}$, Ryan Batley ${ }^{1}$, Pawan Lal ${ }^{1}$, Lara Wakeling ${ }^{3}{ }^{(1)}$ and Mani Naiker ${ }^{1,2, *}$ \\ 1 School of Health, Medical \& Applied Sciences, CQUniversity Australia, Bruce Hwy, \\ North Rockhampton, QLD 4701, Australia; arron.wilson@cqumail.com (A.W.); \\ joel.johnson@cqumail.com (J.B.J.); ryan.batley@cqumail.com (R.B.); lal_rekha@yahoo.com (P.L.) \\ 2 Institute for Future Farming Systems, CQUniversity Australia, Bruce Hwy, \\ North Rockhampton, QLD 4701, Australia \\ 3 School of Science, Psychology and Sport, Federation University Australia, Ballarat, VIC 3350, Australia; \\ 1.wakeling@federation.edu.au \\ * Correspondence: m.naiker@cqu.edu.au
}

check for updates

Citation: Wilson, A.; Johnson, J.B.; Batley, R.; Lal, P.; Wakeling, L.; Naiker, M. Authentication Using Volatile Composition: A Proof-of-Concept Study on the Volatile Profiles of Fourteen Queensland Ciders. Beverages 2021, 7, 28. https:// doi.org/10.3390/beverages7020028

Academic Editors: Anna PicinelliLobo and Christian Ariel Lopes

Received: 30 April 2021

Accepted: 21 May 2021

Published: 25 May 2021

Publisher's Note: MDPI stays neutral with regard to jurisdictional claims in published maps and institutional affiliations.

Copyright: (c) 2021 by the authors. Licensee MDPI, Basel, Switzerland. This article is an open access article distributed under the terms and conditions of the Creative Commons Attribution (CC BY) license (https:// creativecommons.org/licenses/by/ $4.0 /)$.

\begin{abstract}
Although relatively small, the Australian cider industry has experienced significant growth in recent years. One of the current challenges in the industry is the lack of research specific to Australian ciders. Establishing baseline volatile organic compound (VOC) profiles of Australian cider is paramount to developing a better understanding of the industry. This understanding may ultimately be utilized for both the categorization and authentication of existing ciders, and the targeted modification of cider volatiles for the development and improvement of cider quality. This study utilized gas chromatography, coupled with mass spectrometry, to identify key VOCs present in 14 ciders sourced from four different manufacturers in Queensland, Australia. A total of 40 VOCs were identified across the ciders, with significant variation depending on the flavor and manufacturer. Principal component analysis indicated that the ciders were well-separated based on the manufacturer, supporting the prospect of using the volatile composition to discriminate between cider manufacturers. Furthermore, hierarchical cluster analysis highlighted the commonalities and differences in cider composition between different manufacturers, which may be indicative of the varying ingredients and manufacturing processes used to create the ciders. Future studies profiling the volatile composition of larger numbers of Australian ciders are recommended to support the use of this analytical technique for authentication purposes. Likewise, exploration of the relationship between specific processes and VOCs is recommended to fortify an understanding of how to optimize cider production to improve consumer satisfaction.
\end{abstract}

Keywords: volatile organic compounds (VOCs); aroma; cider; volatile phenols; esters; acids; fermented beverages; terpenoids; authentication

\section{Introduction}

Cider is a traditional alcoholic beverage that has been produced throughout history wherever apples are found, with the most prominent cider-producing countries being France, Spain, and England [1]. In Australia, cider accounts for only $2.5 \%$ of the alcohol available for consumption [2], dramatically overshadowed by other beverages, such as beer, wine, and spirits. However, cider consumption within Australia has increased by $11.8 \%$ over the past five years [2]. This increase in cider consumption has been accompanied by a similar trend in local cider production, with organisations such as Cider Australia working towards strengthening Australian cider production to implement industry initiatives, such as the Australian trust mark. This mark indicates that the cider has been produced from 100\% Australian-grown materials, guaranteeing the beverage's authenticity for the consumer [3]. 
Despite the current industry growth and interest in improving production techniques and materials, there is a current lack of research surrounding Australian ciders. Australian cider research has been scarce, with much of the technological knowledge being adapted from the extensive research conducted in the beer and wine industries [4]. More recently, there has been a shift of focus towards developing a better understanding of the relationship between the materials and processes used to make ciders and their volatile organic compound (VOC) profiles.

Cider flavour is strongly influenced by a complex mixture of compounds, with VOCs such as 2-phenylethanol [5], diethyl malate [6], octanoic acid [7], and 6-methyl-5-hepten-2one being identified as important contributors. Similarly, acetates, butanoic and hexanoic acids, and hexanol also play important roles in influencing flavour and aroma [8-13].

In recent international studies, the VOC composition of ciders has been related and associated with technologies and practices of the different stages of cider production. All processes throughout cider manufacturing can impact on the VOC composition, including the production of the apple must, second-stage fermentation, and the maturation stage [14]. Factors involved in the first stage include variety of apple used, fruit preparation, fruit pressing techniques, and must clarification $[4,15]$. The VOC composition of apples differs greatly between varieties. Kakiuchi et al. [16] were able to discriminate between apple varieties, and growth regions within varieties using gas chromatography-mass spectroscopy (GC-MS). Holland, et al. [17] found that Fuji apples contain high levels of 2-methyl butyl acetate, compared to Granny Smith apples, which tend to accumulate hexyl acetate. Similarly, Young, et al. [12] found that butanol is one of the most impactful aroma compounds in Royal Gala apples, while Villatoro, et al. [18] found that Pink Lady apples contain high levels of hexyl 2-methylbutanoate compared to other varieties. Furthermore, it is important to note that temporal factors can also affect the volatile composition of apples within varieties. In work conducted by López, et al. [13], Golden Delicious and Granny Smith apples from consecutive years contained different relative VOC compositions. Despite the importance of understanding the relationship between apple variety and cider VOC profiles, research in the area is limited [4], and often hindered by the complicated and dynamic change to existing apple volatiles during fermentation [15]. However, recent research has endeavored to rectify this lack of knowledge; for example, Rosend, et al. [4] found that apple variety had the primary influence on the VOC composition of Estonian ciders, followed by the effect of yeast strains and apple maturity. Ciders from two of the apple varieties (Antei and Melba) showed quite distinct VOC profiles, while those from two other varieties (Kulikovskoye and Orlovski Sinap) showed very similar VOC profiles to one another and could not be discriminated. Medina, et al. [19] was able to use the volatile composition of Portuguese ciders as a biomarker for the apple variety used. However, there is limited information available on the commonality of VOC profiles within commercial cider products produced by a single manufacturer, who may use different apple varieties but with the same cider manufacturing processes.

Important variables associated with the second processing stage of ciders include the yeast strains used in the fermentation process [4], biomass reduction, and maturation [20,21]. The role of yeast strain in the VOC content of cider is of current research interest, with Lorenzini, et al. [14] analysing the VOC profile of ciders produced by seven different yeasts. The results indicated potential for utilizing specific yeast strains to achieve selection for certain desirable volatiles; for example, 2-phenylethanol was found at a higher concentration in ciders produced by Saccharomyces uvarum and Hanseniaspora uvarum [14]. Additionally, the use of nonconventional yeast species can also be used to improve cider VOC profiles through the reduction of undesirable volatiles. He, et al. [22] found that cider fermentation using Schizosaccharomyces pombe resulted in lower concentrations of malic acid, ethyl pentanoate, and ethyl hexanoate, whilst retaining higher residual sugars. Overall, this resulted in a cider that was described as sweeter and honey-like when compared to S. cerevisae fermented ciders. Another technological process that can impact on volatile composition is biomass reduction, which is a practice in which yeast cells are removed 
during fermentation, creating a low nitrogen environment [23]. This reduces the speed of fermentation and allows greater control over the process, improving cider sweetness and promoting fruity ester production. Villière, et al. [21] found that while biomass reduction increased residual sugar content, the only volatiles favoured by the process were butanoic acid and 3-methylbutanoate. This indicates that the degree of biomass reduction needs to be tailored specifically to the must, and that further research is required to optimise the process.

The maturation stage of ciders has also been reported to impact the overall sensory perception of cider derivatives. Rodríguez Madrera, et al. [24] found that greater maturation of the ciders selected for distillation provided cider spirits with better sensory ratings. In turn, the sensory evaluation of the cider spirits improved with longer maturation times. Over the period studied (2 years), the concentrations of compounds such as ethyl acetate, ethyl lactate, diethyl succinate, and acetal declined, while the concentration of $\mathrm{C}_{12}, \mathrm{C}_{14}$, and $\mathrm{C}_{16}$ fatty acid ethyl esters was found to increase [25].

These relationships are yet to be explored within the context of Australian ciders. However, such studies are hampered by a lack of basic contextual data on the volatile composition of Australian-made ciders.

The work presented here aims to establish a snapshot of the current VOC makeup of ciders produced in southern Queensland. This will provide valuable baseline information on the composition of Queensland-made ciders, as well as building a foundation which can be used as an authentication technique for discriminating between cider manufacturers or the detection of adulterated products. In addition, these techniques could be utilised in future research into the correlation between favourable VOCs and the impact of specific cider making practices and technologies. Consequently, this could provide a tool for improving cider product quality through targeted modifications of their VOC profile.

The specific aims of this study were to:

1. Profile the VOC composition of commercial southern Queensland ciders;

2. Determine if VOC composition could be used as a means of discriminating between ciders produced by different manufacturers.

\section{Materials and Methods}

\subsection{Reagents}

All reagents used were of analytical grade. Dichloromethane (DCM) was purchased from Merck Australia (Sydney, Australia). Anhydrous sodium sulphate and alkane standards $\left(\mathrm{C}_{8}-\mathrm{C}_{20}\right)$ were purchased from Sigma Aldrich Australia (Sydney, Australia).

\subsection{Cider Samples}

Fourteen cider samples were sourced from the four commercial cider manufacturers found in Queensland, Australia (Table 1). All samples were sourced at the same time of year. The apples used by all four manufacturers were all grown within the Granite Belt region in south-east Queensland. The region itself is centered on the town of Stanthorpe (28.6552 $\mathrm{S}$, $151.9345^{\circ} \mathrm{E}$ ), and is well known for its apple production. The collection of ciders in this study incorporates the entirety of commercial ciders brewed in this geographical region (Queensland). The specific apple variety used to make the cider was only available for five of the ciders (ciders 1, 7, 8, 12, and 13; Table 1), as this information is typically kept as a manufacturer trade secret. Similarly, the exact manufacturing processes of most ciders were not provided by the manufacturers due to trade secrecy. However, the aim of this study was not to correlate the VOC composition to specific apple varieties or manufacturing processes, but rather to provide baseline information on the VOC profiles of commercial Queensland ciders and investigate the commonalities and variation in VOC profiles between different manufacturers. 
Table 1. Details of the 14 cider samples tested in this study.

\begin{tabular}{|c|c|c|c|c|c|}
\hline Cider & Manufacturer & Region of Manufacture & Description from Label & Manufacturing Information & Ethanol Content $(\%)$ \\
\hline 1 & A & Stanthorpe, QLD & Medium dry, hazy & $70 / 30 \%$ red/green apples. Champagne yeast used & 4.8 \\
\hline 2 & $\mathrm{~B}$ & Sunshine Coast, QLD & Medium dry & 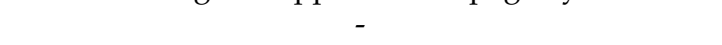 & 4.8 \\
\hline 3 & $\mathrm{~B}$ & Sunshine Coast, QLD & Bone dry, fruit with a honey note, wine-like & - & 7.0 \\
\hline 5 & $\mathrm{C}$ & Bundaberg, QLD & Contains ginger and orange & - & 8.0 \\
\hline 6 & $\mathrm{C}$ & Bundaberg, QLD & Contains passionfruit & - & 8.0 \\
\hline 7 & $\mathrm{C}$ & Bundaberg, QLD & Dry & Royal Gala, Fuji, and Granny Smith apples ^ & 6.2 \\
\hline 8 & $\mathrm{C}$ & Bundaberg, QLD & Sweet & Royal Gala and Red Delicious apples` & 6.1 \\
\hline 10 & $\mathrm{D}$ & Tamborine Mountain, QLD & Botanical, bright, spicy; contains ginger & - & 5.0 \\
\hline 11 & $\mathrm{D}$ & Tamborine Mountain, QLD & Contains shiraz wine & - & 5.0 \\
\hline 12 & $\mathrm{D}$ & Tamborine Mountain, QLD & Crisp, juicy & Made from Pink Lady apples^ & 5.2 \\
\hline 13 & $\mathrm{D}$ & Tamborine Mountain, QLD & Dry, champagne-like & Made from Granny Smith apples ^ & 5.9 \\
\hline 14 & B & Sunshine Coast, QLD & Dry, sparkling & Bottle fermented, champagne method & 8.5 \\
\hline
\end{tabular}

` the apple varieties used in the other ciders were not specified by the manufacturer due to trade secrecy. - indicates that the information was not available due to trade secrecy. 


\subsection{Extraction Procedure}

To extract the VOCs from the cider samples, DCM $(0.8 \mathrm{~mL})$ was added to $5 \mathrm{~mL}$ of each cider sample aliquot and one procedure blank $(n=15)$. One replicate extraction was performed per cider. These were homogenized for $15 \mathrm{~min}$ using a Ratek RM4 end-over-end shaker (Melbourne, Australia), operating at $50 \mathrm{rpm}$. On completion, the organic layer was separated and collected in a $1.5 \mathrm{~mL}$ vial. This extraction protocol was repeated a second time with another $0.8 \mathrm{~mL}$ of DCM to optimize the VOC extraction efficiency. Anhydrous sodium sulphate was added in excess to the combined DCM extract to remove the presence of any water, before carefully withdrawing the dehydrated DCM soluble supernatant for subsequent analysis. The DCM extracts were filtered $(0.45 \mu \mathrm{m}$ polytetrafluoroethylene (PTFE); Livingstone brand; Sydney, Australia) before analysis by gas chromatographymass spectroscopy (GC-MS).

\subsection{VOC Analysis by GC-MS}

GC-MS analysis was conducted on the DCM extracts using a Shimadzu 2010Ultra instrument (Kyoto, Japan) fitted with an Rtx-5MS column $(30 \mathrm{~m} \times 0.25 \mathrm{~mm} \times 0.25 \mu \mathrm{m}$; Kyoto, Japan). Nitrogen was used as the carrier gas at $1 \mathrm{~mL} \mathrm{~min}^{-1}$, with an injection volume of $0.5 \mu \mathrm{L}$. The injection temperature was $250{ }^{\circ} \mathrm{C}$, with an initial oven temp of $40{ }^{\circ} \mathrm{C}$; ramped at $7{ }^{\circ} \mathrm{C} \mathrm{min}^{-1}$ to $190{ }^{\circ} \mathrm{C}(2 \mathrm{~min}$ hold $)$, followed by a $20^{\circ} \mathrm{C} \mathrm{min}{ }^{-1}$ ramp to $250^{\circ} \mathrm{C}$ ( 2 min hold). Peak identification was conducted primarily using an automatic integration function based on peak height; additional manual integration was conducted based on the similarity search result ( $>85 \%$ was included). Linear retention indices (LRI) were calculated for each compound following the method of van Den Dool and Kratz [26], based on the elution times of a series of alkane standards $\left(\mathrm{C}_{8}-\mathrm{C}_{20}\right)$ injected using identical chromatographic conditions.

Compound identification was accomplished using the similarity search function of the NIST14s GC-MS library; compounds with a close spectral match (greater than $85 \%$ similarity) and a similar LRI were identified; compounds with lower similarity matches or different LRI values were only tentatively identified according to similarity of MS spectra, and LRI in compounds detected in similar research.

\subsection{Chemometric Analysis}

The chemometric data analysis was performed using the Unscrambler X (version 10) (Camo Analytics; Oslo, Norway). To investigate the relationships between different cider samples and the intercorrelations between individual VOCs, the exploratory data reduction technique of principal component analysis (PCA) was utilized. This is a commonly used technique for reducing datasets containing a large number of variables to just a few variables (termed principal components), which are easier to interpret [27].

Prior to performing the PCA, the dataset was normalized by dividing each value by the standard deviation for that compound. This ensured that compounds in relatively higher concentrations did not exert an undue influence on the analysis. In order to further investigate the overall similarity in the composition of the cider samples, the unsupervised clustering technique of hierarchical cluster analysis (HCA) was also performed.

This also used the normalized dataset, along with a hierarchical single-linkage clustering method and a Euclidean distance measure. This data analysis technique was used to identify different "clusters", comprising ciders which possess similar volatile profiles.

\section{Results and Discussion}

Across the 14 ciders analyzed, a total of 40 distinct peaks were detected (Figure 1). A total of 36 of these were identified from their mass spectra and LRI, while the remaining four were tentatively identified using either their mass spectrum or their LRI. Of the 40 compounds, esters, phenols, acids, and monoterpenes made up $67.5 \%$ of the overall VOC diversity. Alcohols, ketones, furans, ethers, acetals, and aldehydes accounted for the remaining $32.5 \%$ VOC diversity (Table 2). The peak areas of each compound were 
used to calculate the relative abundance of the compounds present in each cider, as shown in Table 3.

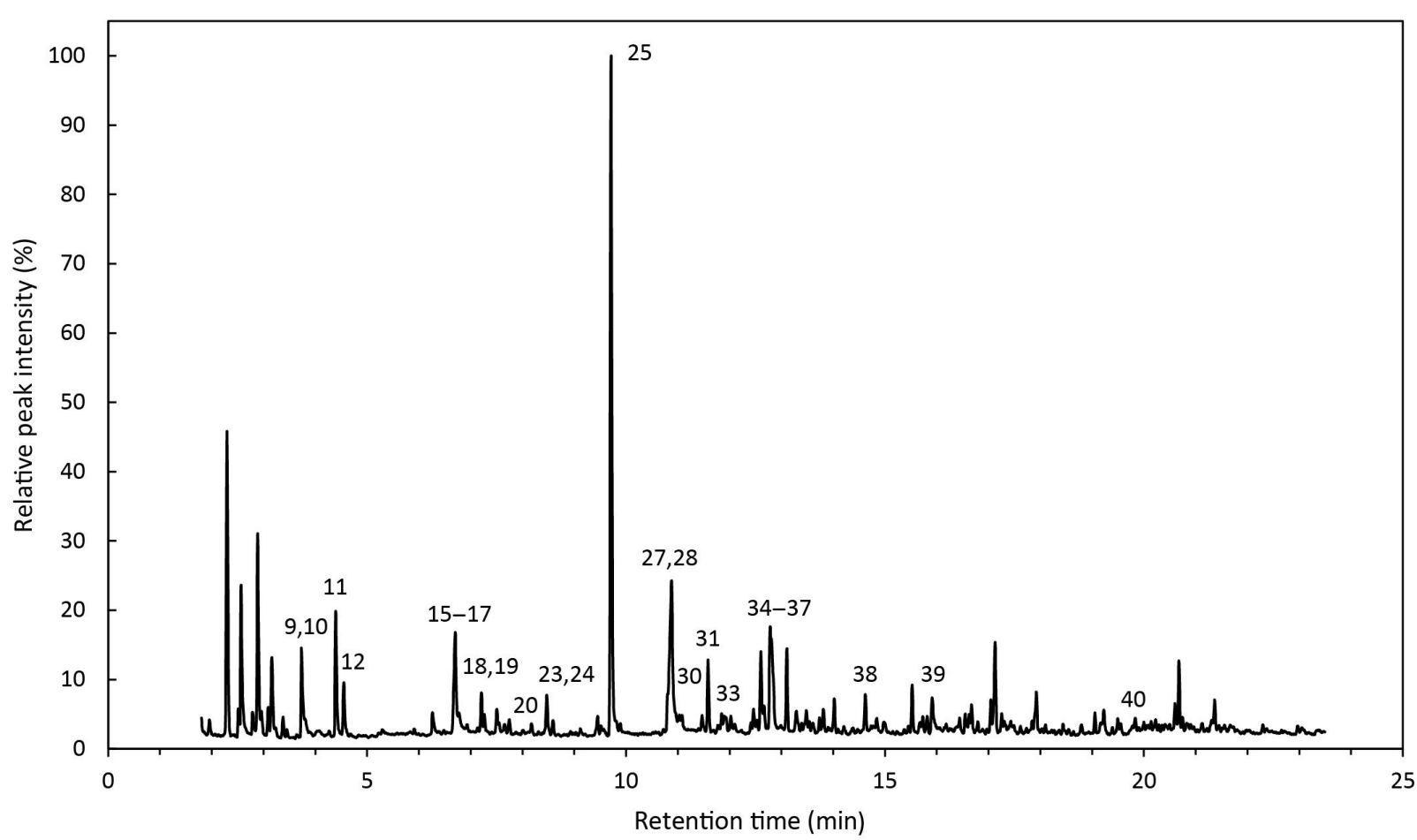

Figure 1. A representative gas chromatogram from one of the cider samples (cider 11). Compound numbers correspond to those provided in Table 3.

Table 2. The different classes of chemical compounds found across the 14 analyzed ciders, each represented by the number of individual compounds and percentage of volatile diversity.

\begin{tabular}{ccc}
\hline $\begin{array}{c}\text { Chemical Class Based on } \\
\text { Functional Group }\end{array}$ & $\begin{array}{c}\text { Number of Individual } \\
\text { Compounds }\end{array}$ & $\begin{array}{c}\text { Percentage of Volatile } \\
\text { Diversity }\end{array}$ \\
\hline Esters & 8 & 20 \\
Alcohols & 7 & 17.5 \\
Acids & 6 & 15 \\
Monoterpenes & 6 & 15 \\
Volatile phenols & 5 & 12.5 \\
Ketones & 3 & 7.5 \\
Furans & 2 & 5 \\
Ethers & 1 & 2.5 \\
Acetals & 1 & 2.5 \\
Aldehydes & 1 & 2.5 \\
\hline Total & 40 & 100 \\
\hline
\end{tabular}

\subsection{Esters}

Esters are an essential group of sensory active compounds within cider and are recognized as primarily responsible for the pleasant, fruity, and floral qualities they impart [7]. Esters are found within both apple flesh and apple juice; however, most esters are understood to form during the fermentation process through the esterification of acetylCoA molecules and the various alcohols that are produced during cellular metabolism of yeasts [21]. Increased cider maturation time allows for the continued esterification of fatty acids and alcohols, resulting in an increase in esterified compounds, with a concurrent decrease in higher alcohol concentration [20]. 
Of the esters identified, the most abundant was diethyl maleate, which was present in 13 of the 14 ciders and is associated with a caramel odor [6]. This was followed by hexyl 2-methylbutanoate, which is associated with a fresh green and fruity aroma. This compound is found in highest concentrations in Pink Lady apples [18], as compared to other varieties, such as Gala [28] and Fuji [29].

Notably, hexyl 2-methylbutanoate was detected at much higher levels in the only cider listed as containing Pink Lady apples (cider 12). Propyl propionate, an ester commonly found in apple juice [30] and associated with apple, banana, and pineapple flavours [31], was found in 13 of the ciders. Pentyl acetate, which is described as having a fruity odour [5], was also detected in 13 of the 14 ciders and is perceived to have a minor impact on overall cider quality due to its low aroma threshold [5]. Whilst isopropyl 2-methylpropanoate was tentatively identified in all 14 ciders, its presence as a common VOC in either apples or cider has not been reported. Diethyl succinate has been previously reported from cider spirits, with its concentration reported to significantly decrease in cider spirits during their maturation in inert vessels [25]. There is no reported organoleptic impact of diethyl succinate in cider; however, it has been reported to have minimal impact on the aroma profile of Australian port wine [32].

Ethyl hexanoate and ethyl octanoate accounted for the detected ethyl esters, which are the product of esterification of fatty acids with ethanol. As fatty acids would only be found at trace levels within typical cider fermentations, the resulting ethyl esters would be expected to only be found at trace levels [33]. Nicolini, et al. [34] analysed ciders produced from single apple varieties: Golden Lasa, Braeburn, Granny Smith, Fuji, Reinette Champaign, and Reinette dessert apples. They found that ethyl hexanoate and ethyl octanoate concentrations were highest in Fuji based ciders brewed using Saccharomyces cerevisiae yeast strains: Fermicru LS2 and Zymaflore VL1. Although the ethyl hexanoate levels were not the highest in the cider listed as containing Fuji apples (cider 7), it is worth noting that this cider did contain the highest ethyl octanoate levels. As a subgroup, they make up most of the unique ester compounds found in ciders [5]. Responsible for fruity, sweet [35], green [36], and fermented notes [37], these ethyl esters are generally positively correlated with a sluggish, stressful fermentation in ciders [21].

Ethyl octanoate levels have previously been observed to increase during fermentation of cider, before sharply declining on the final day of fermentation [15]. This reduction is likely due to the hydrolysis of these esters by the esterase enzymes produced by the yeast at the final stages of fermentation [15]. Of the 14 ciders analysed, the presence of ethyl octanoate was confirmed in 9 . It is plausible that the fermentation period for these nine ciders may have been reduced to preserve some of the sugars to improve the sweetness of the product, inadvertently preventing the enzymatic hydrolysis which commonly occurs during the final days of fermentation. Ethyl octanoate is also positively correlated with the practice of biomass reduction [21]. Furthermore, the low nitrogen environment favours oxidative respiration of the yeast cells, producing more desirable aroma-active compounds [23]. Additionally, biomass reduction is advantageous for the process of natural gasification, in which carbon dioxide is produced by yeast cells within the bottle to produce a carbonated beverage, a method developed for the natural gasification of champagne [23]. In contrast, ethyl hexanoate-responsible for fruity and fermented odours-is negatively correlated with biomass reduction during fermentation of cider [21]. 
Table 3. Relative percent composition of the detected VOCs across the 14 analyzed ciders. The highest value found for each compound is highlighted in bold.

\begin{tabular}{|c|c|c|c|c|c|c|c|c|c|c|c|c|c|c|c|c|c|c|c|c|}
\hline \multirow{2}{*}{ No. } & \multirow{2}{*}{ Retention Time } & \multirow{2}{*}{ Compound } & \multirow{2}{*}{ Chemical Class } & \multirow{2}{*}{ Ident. Method } & \multirow{2}{*}{ LRI $^{\wedge}$} & \multirow{2}{*}{ Lit. LRI^^ } & \multicolumn{14}{|c|}{ Cider Sample } \\
\hline & & & & & & & 1 & 2 & 3 & 4 & 5 & 6 & 7 & 8 & 9 & 10 & 11 & 12 & 13 & 14 \\
\hline 1 & 2.29 & Diethyl acetal & Acetal & MS, LRI & 756 & $734[38]$ & 12.9 & 6.0 & 14.5 & 7.5 & 6.6 & 5.9 & 4.8 & 4.1 & 5.8 & 7.6 & 12.2 & 13.8 & 9.5 & 4.7 \\
\hline 2 & 2.50 & Butanoic acid & Acid & MS, LRI & 766 & $775 *$ & - & - & - & - & - & - & - & - & - & 0.7 & 0.9 & 0.6 & 0.2 & - \\
\hline 4 & 2.79 & 2,3-Butanediol & Alcohol & LRI & 779 & $770[39]$ & 0.5 & 0.6 & 1.1 & - & - & - & - & - & - & 0.4 & 0.8 & 0.6 & 0.4 & - \\
\hline 5 & 2.88 & 3-Hexen-2-one & Ketone & MS, LRI & 783 & $762 *$ & 5.3 & 5.0 & 9.8 & 10.7 & 11.0 & 7.9 & 8.1 & 7.8 & 10.1 & 6.2 & 7.2 & 7.2 & 7.0 & 7.0 \\
\hline 6 & 3.09 & 3-Methoxy-1-butanol & Alcohol & MS, LRI & 792 & $773 *$ & 0.5 & 0.6 & 1.4 & 1.4 & 1.5 & 1.2 & 1.2 & 1.1 & 1.4 & 0.7 & 1.0 & 1.0 & 1.0 & 0.9 \\
\hline 7 & 3.16 & Isopropyl 2-methylpropanoate & Ester & LRI & 796 & $780[40]$ & 2.4 & 3.1 & 9.6 & 6.7 & 4.5 & 3.3 & 3.3 & 3.2 & 4.1 & 2.5 & 3.0 & 3.1 & 3.0 & 2.9 \\
\hline 8 & 3.62 & Furfural & Furan & MS, LRI & 819 & $830[39]$ & 0.6 & - & - & - & - & 0.1 & - & - & - & - & - & - & - & - \\
\hline 10 & 3.81 & Diacetone alcohol & Ketone & MS, LRI & 829 & 829 [41] & 0.3 & 0.3 & 1.2 & 0.9 & 1.1 & 0.9 & 1.0 & 0.8 & 1.3 & 0.4 & 0.4 & 0.3 & 0.2 & 0.8 \\
\hline 11 & 4.40 & 1-Hexanol & Alcohol & MS, LRI & 859 & $867[39]$ & 1.7 & 1.3 & 1.7 & 0.5 & 0.8 & 1.9 & 2.0 & 1.5 & 2.2 & 0.6 & 4.9 & 7.7 & 0.9 & 1.0 \\
\hline 12 & 4.55 & Pentyl acetate & Ester & MS, LRI & 867 & $884 *$ & 0.3 & 0.2 & 0.1 & 0.1 & 0.2 & 0.4 & 0.2 & 0.2 & 0.1 & 1.4 & 2.0 & 1.9 & 1.2 & - \\
\hline 13 & 5.27 & 4-Hydroxy-butanoic acid & Acid & MS, LRI & 904 & $933[42]$ & - & 0.8 & 0.4 & - & - & - & - & - & - & 0.1 & - & - & 0.2 & - \\
\hline 14 & 6.43 & Benzaldehyde & Aldehyde & MS, LRI & 959 & $950[41]$ & - & - & - & - & - & 1.3 & - & - & - & - & - & - & - & - \\
\hline 15 & 6.67 & Hexanoic acid & Acid & MS, LRI & 970 & 1019 [43] & 1.1 & 0.2 & 1.2 & 0.3 & 0.9 & 1.2 & 1.6 & 2.1 & 0.8 & 4.8 & 5.4 & 4.3 & 5.2 & - \\
\hline 16 & 6.78 & Methionol & Alcohol & MS, LRI & 975 & $978[43]$ & 0.6 & 0.8 & 0.4 & 0.7 & - & 0.1 & 0.2 & 0.2 & 0.2 & 0.2 & 0.4 & - & - & 0.6 \\
\hline 17 & 6.91 & 6-Methyl-5-hepten-2-one & Ketone & MS, LRI & 981 & $966[44]$ & - & - & 0.2 & - & 0.4 & 0.2 & 0.2 & 0.2 & 0.2 & 0.9 & 0.3 & - & 0.2 & 0.2 \\
\hline 18 & 7.21 & Ethyl hexanoate & Ester & MS, LRI & 996 & $997[45]$ & 0.3 & - & 0.3 & 0.3 & 0.6 & 0.5 & 0.7 & 2.1 & 0.2 & 0.9 & 1.1 & 0.9 & 1.0 & - \\
\hline 19 & 7.26 & 1,4-Diethoxy-2-butene & Ether & MS & 998 & $976 *$ & 0.4 & 0.3 & 0.3 & 0.4 & 0.2 & 0.3 & 0.2 & 0.3 & 0.3 & 0.5 & 0.5 & 0.4 & 0.6 & 0.4 \\
\hline 22 & 8.78 & Sorbic acid & Acid & MS, LRI & 1070 & $1045[47]$ & - & - & - & - & 25.9 & 30.8 & 47.8 & 52.3 & 49.9 & - & - & - & - & - \\
\hline 23 & 9.44 & Linalool & Terpenoid & MS, LRI & 1099 & $1090[41]$ & - & 0.4 & 0.3 & 0.7 & 2.1 & 0.9 & 0.4 & 0.4 & 0.3 & 2.1 & 0.7 & 0.4 & 0.7 & 0.2 \\
\hline 24 & 9.51 & Dihydromyrcenol & Terpenoid & LRI & 1102 & 1080 * & 0.2 & & 0.3 & 0.6 & 0.5 & 0.5 & 0.3 & 0.4 & 0.6 & 0.2 & 0.2 & 0.2 & 0.3 & 0.4 \\
\hline 25 & 9.71 & 2-Phenylethanol & Alcohol & MS, LRI & 1112 & $1110[46]$ & 54.9 & 59.8 & 35.1 & 52.7 & 25.0 & 19.1 & 14.8 & 13.3 & 12.9 & 28.4 & 27.7 & 23.9 & 32.3 & 60.3 \\
\hline 26 & 10.65 & Benzoic acid & Acid & MS, LRI & 1156 & $1171[48]$ & - & - & - & - & - & 1.0 & - & - & - & - & - & 1.9 & - & - \\
\hline 27 & 10.79 & 2-Ethylphenol & Phenol & MS, LRI & 1162 & $1169[43]$ & 0.6 & 5.3 & 6.1 & 1.1 & - & - & - & - & - & - & 1.2 & 0.9 & 6.8 & 4.9 \\
\hline 28 & 10.87 & Octanoic acid & Acid & MS, LRI & 1166 & $1179[45]$ & 2.2 & 0.7 & 2.7 & 3.8 & 5.8 & 2.7 & 4.3 & 3.4 & 2.1 & 10.1 & 9.5 & 3.9 & 4.1 & - \\
\hline 29 & 11.03 & Endo-Borneol & Terpenoid & MS, LRI & 1174 & 1157 [41] & - & - & - & - & 0.6 & - & - & - & - & 1.4 & - & - & - & - \\
\hline 30 & 11.08 & Diethyl succinate & Ester & MS, LRI & 1176 & 1179 [39] & - & 1.2 & 3.9 & 3.7 & 1.1 & 0.7 & 0.2 & - & 0.2 & - & 0.3 & 0.1 & 1.1 & 4.9 \\
\hline 31 & 11.47 & Ethyl octanoate & Ester & MS, LRI & 1195 & 1195 [49] & - & - & 0.5 & 0.3 & - & 0.2 & 0.6 & 0.4 & 0.2 & - & 0.5 & 0.4 & 0.5 & - \\
\hline 32 & 11.50 & Alpha-terpineol & Terpenoid & MS, LRI & 1196 & $1185[50]$ & - & - & - & 1.3 & 3.2 & 0.2 & - & - & - & 4.0 & - & - & 3.2 & - \\
\hline 33 & 11.89 & Coumarin & Furan & MS, LRI & 1215 & $1224[51]$ & 0.9 & 0.2 & 0.3 & - & 0.6 & 0.5 & 0.5 & 0.7 & 0.4 & 0.3 & 0.3 & 0.7 & 0.5 & - \\
\hline 34 & 12.10 & Citronellol & Terpenoid & MS, LRI & 1226 & 1228 [39] & - & - & - & - & - & - & - & - & - & 1.1 & 0.2 & - & - & - \\
\hline 35 & 12.60 & Chavicol & Phenol & MS, LRI & 1250 & $1253[39]$ & 0.2 & 1.0 & 1.0 & 0.7 & 0.6 & 4.2 & 2.2 & 2.0 & 1.1 & 1.9 & 2.6 & 1.3 & - & 0.5 \\
\hline 36 & 12.78 & Hexyl 2-methylbutanoate & Ester & MS, LRI & 1259 & $1236[52]$ & 5.9 & 2.1 & - & - & - & - & 0.6 & 0.2 & 1.6 & 4.5 & 4.0 & 18.3 & - & - \\
\hline 37 & 12.82 & Diethyl maleate & Ester & MS, LRI & 1261 & $1313 *$ & 0.4 & 1.1 & 4.4 & 2.6 & 2.9 & 2.4 & 0.9 & 0.9 & 1.0 & 2.3 & 0.6 & - & 14.2 & 8.6 \\
\hline 38 & 14.62 & Eugenol & Phenol & MS, LRI & 1353 & $1340[41]$ & - & 0.8 & 0.4 & 0.5 & 0.2 & 1.4 & 0.7 & 0.5 & 0.3 & 0.6 & 1.1 & - & - & - \\
\hline 39 & 15.90 & Tyrosol & Phenol & MS, LRI & 1421 & 1356 * & 4.6 & 3.3 & 2.3 & 2.4 & 0.6 & 0.7 & 0.5 & - & - & 1.3 & 1.5 & 0.9 & 1.1 & 1.6 \\
\hline 40 & 19.73 & Zingerone & Phenol & MS, LRI & 1641 & 1653 [53] & - & - & - & - & 0.5 & - & - & - & - & 1.6 & - & - & - & - \\
\hline
\end{tabular}

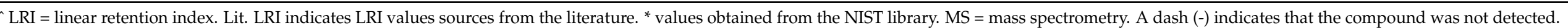




\subsection{Alcohols}

Alcohols are biosynthesized by plants during fruit ripening, and produced during the fermentation process [54]. Associated with honey and whiskey imparting aromas [55], alcohols generally provide positive effects on the overall aroma profile of ciders. However, at concentrations above $400 \mathrm{mg} \mathrm{L}^{-1}$, some alcohols develop an unpleasant flavor and a harsh, unfavorable taste [54]. Reduced concentrations of alcohols are found in ciders that have undergone pre-fermentation heat treatment, which removes the initial alcohols formed from fruit ripening [56]. Additionally, the practice of must clarification, in which colloidal pectin, cell wall fragments, and pulp are removed [57], has been shown to reduce alcohol concentration in both wines [54] and ciders [58].

The most abundant alcohol was found to be 2-phenylethanol, which is formed from the metabolic transformations of phenylamine via the Ehrlich pathway during fermentation [59]. Found at trace levels in apple juices, 2-phenylethanol increases drastically during fermentation, making it one of the most abundant aromatic compounds within cider [60]. It has an aroma threshold (in 10\% ethanol) of $10 \mathrm{mg} / \mathrm{L}$ [5], and imparts floral and honey odors [36]. It is commonly found in other fermented products, such as wine, whiskey, and rum $[5,36]$.

The abundance of 2-phenylethanol has been found to be directly proportional to the abundance of amino acids added to nitrogen-deficient wine fermentations [61]. Research into the large-scale biotransformation of 2-phenylethanol for the cosmetic industry has indicated that higher yields are achieved when L-phenylalanine is provided as the sole source of nitrogen for the fermentation [62]. It is possible that the addition of L-phenylalanine after successful biomass reduction could trigger increased production of 2-phenylethanol, which is desirable for their aroma profiles. However, further research would be needed to confirm the linearity of the addition of L-phenylalanine with the production of 2-phenylethanol under these conditions.

All 14 ciders contained 1-hexanol, which is produced from the bioremediation of unsaturated fatty acids [63] and contributes to a nutty or musty aroma. It has also been previously noted that the presence of 1-hexanol has a suppressive effect on "apple" aromas [64]. Eleutério dos Santos, et al. [65] found that cider produced from Royal Gala apples contains relatively high levels of 1-hexanol (as compared to Gala variety) regardless of the yeast strain used. Although the ciders containing the highest 1-hexanol levels did not correspond to the ciders listed as containing Royal Gala apples (ciders 7 and 8), it is possible that some of the other ciders did also contain the Royal Gala variety, thus explaining their elevated levels of 1-hexanol. Additionally, through the action of alcohol acetyltransferase (AAT) enzyme [66], 1-hexanol is converted to hexyl acetate, which is a favorable aroma-imparting compound in both wines and cider, known for its enhancement of floral and sweet odors $[63,64,66,67]$. The targeted conversion of 1-hexanol to hexyl acetate through addition of the AAT enzyme post-fermentation may prove advantageous for the improvement of cider olfactory properties. Although hexyl acetate was not assessed in this study, it is possible that the 1-hexanol in the Royal-Gala-containing ciders may have been converted to hexyl acetate post-fermentation, which could account for the relatively low 1-hexanol concentrations observed in this study.

The typical presence of 2,3-butandiol in cider is due to the diacetyl metabolism by lactic-acid-producing bacteria [68] and is often described as buttery or creamy, with an aroma threshold of $120 \mathrm{mg} \mathrm{L}^{-1}$ (10\% ethanol) [69]. 2,3-butandiol is recognized as a valuable aroma-imparting compound within cider, and is responsible for enhancing the cider's global aroma intensity [68].

3-ethoxy-1-propanol was found in most of the cider samples, at concentrations between 0.2 and $3.8 \%$. It is an aroma-active compound producing a fruity aroma at a sensory threshold of $0.1 \mathrm{mg} \mathrm{L}^{-1}$ (in 14\% ethanol) [70]. Produced by yeast metabolism in beer and cider, 3-ethoxy-1-propanol is generally found in trace concentrations. However, if the cider undergoes distillation, 3-ethoxy-1-propanol will be collected in the final fractions of distillation due to its amphiphilic nature; the ether in these distilled beverages is somewhat 
dependent on the distillation procedures used [70]. 3-Methoxy-1-butanol was found at trace levels in all the analyzed ciders; there are no reports of the occurrence of this compound in apples or apple-based drinks. However, the compound has been identified in grape skins [71] and lavender honey [72].

Benzyl alcohol-the main VOC found in passionfruit, known for its fruity and green odors [73] — was also detected in in this study (in cider 6). Similarly, zingerone-a primary odor-imparting compound of ginger, formed through the action of alkali or heat on its gingerol precursor [74] - was detected in both the ciders listed as being ginger flavored (ciders 5 and 10).

Methionol is a sulphur-containing fusel alcohol, formed from the degradation of sulphur-containing pesticides and methionine metabolism [75]. Methionol is associated with cabbage and cauliflower odours [75], and is described as harming the aroma profile of wines [75]. It was only found in low concentrations in the cider samples, with the highest levels in cider 2, a medium-dry apple cider.

\subsection{Acids}

Acids are responsible for the sour and fresh flavors, alongside rancid or cheesy odors of ciders. The acids found in ciders have two origins: those that are naturally found in apples and other fruits used in the production process [76], as well as those produced via lipid oxidation during the fermentation process $[4,15,76]$. Acids are described as having exceptionally high aroma intensities [5], and have been estimated to account for up to $15 \%$ of ciders' volatile aroma profile [7]. Additionally, acids are essential in maintaining the $\mathrm{pH}$ of the cider and providing resistance to microbial spoilage [60], and are often used as naturally occurring preservatives.

Of the acids that would have an apparent influence towards the ciders' overall volatile profile, octanoic and hexanoic acid were the most abundant in the ciders included in this study $[15,20,60]$. Octanoic acid, a product of lipid oxidation, is associated with the soapy, green, cheese, and fatty aromas $[7,77]$, while hexanoic acid is associated with a rancid, cheesy aroma $[60,78]$. High concentrations of hexanoic acid are typically associated with yeast strain EC1118, commonly used in wine fermentation [4]. Ciders 10-13, which were all from manufacturer $\mathrm{D}$, contained relatively high levels of hexanoic acid, indicating that this manufacturer may use EC1118, or a similar strain of yeast.

Butanoic acid, while not particularly abundant within the tested ciders (only found in samples 10-13), is one of the few compounds which has been positively correlated with biomass reduction [21]. Butanoic acid is generated during the fermentation process through amino acid catabolism, which occurs more frequently with reduced biomass [79]. Additionally, butanoic acid is one of the few compounds that is correlated with the apple variety used in fermentation, and is more prevalent in sharp cider apples [21]. However, as the apple variety was only listed on the label of one cider, it was impossible to correlate butanoic acid contents to specific apple types in this study. Responsible for cheesy and rancid notes, butanoic acid is also correlated with a reduced concentration of fruity aromas [21], which is generally accepted as a valuable cider characteristic. Hence, lower butanoic acid concentrations may be a suitable indicator for ciders with improved quality.

Other acids which have a lesser impact on the quality of ciders were also detected. One such example was the presence of 4-hydroxy-butanoic acid, a precursor to 4-hydroxybutonate, which is a common ester in ciders [17]. Preservatives commonly used in beverage manufacturing were also found within the tested ciders. Benzoic acid, which is used as an antibacterial agent [80], was found in two ciders (samples 6 and 12), while sorbic acid, used as an antifungal agent [80], was found in relatively higher concentrations in ciders $5-9$, all of which were from the same manufacturer.

\subsection{Monoterpenes}

Monoterpenes are numerous and structurally diverse, naturally occurring compounds, found only in trace concentrations in cider; however, they still have strong influence on the 
organoleptic properties [60]. Monoterpenes are primarily derived from the fruit used in fermentation and are metabolized through esterification during fermentation [15]. Additionally, monoterpenes have been identified as a point of interest in developing geographic biochemical profiling in ciders due to the strong dependence of cider monoterpene content directly on the fruit source [7]. However, emerging research with non-Saccharomyces yeast has highlighted the potential role of fermentation processes in altering terpene content types [81].

Of the all the monoterpenes identified in the sampled ciders, eucalyptol and alphaterpineol were the most abundant, with linalool, endo-borneol, and citronellol detected at low levels.

Eucalyptol, a monoterpenoid found in Eucalyptus leaves [82], is described as having a characteristic fresh and cool odor that positively contributes to the cider's overall flavor profile, possibly through its synergistic interaction with other VOCs [83]. The exact origins of eucalyptol in cider is still unclear; however, it has been proposed that eucalyptol content in wine is related to the proximate presence of vineyards to eucalyptus trees [84]. As only three of the ciders in this study (ciders 5, 10, and 11) were determined to contain eucalyptol, it is unlikely that proximity to eucalyptus was the cause. Eucalyptol is also a major VOC from apple leaves [85], and is also found in Australian ginger [86]. As both ciders 5 and 10 were labelled as ginger flavored, and cider 11 only contained trace levels of eucalyptol, this compound is likely derived from the added ginger product.

The monoterpene alcohols linalool and dihydromyrcenol are often detected together in GC-based analysis, and contribute to the flowery and citrus aromas in wines [87]. Previous research has found that the concentration of linalool is influenced by the yeast strain [14] and the apple variety used in the fermentation of cider [19]. Dihydromyrcenol has not been previously reported in cider; however, it is typically found in blackcurrants, where it is responsible for their citrus and herbal aromas [87]. Borneol is often found in lemon/lime carbonated beverages and is associated with a camphorous odor [88]. Citronellol is scarcely found in ciders; however, it is suspected to originate primarily from the apple cultivar used [89]. Found in two of the ciders (ciders 10 and 11), citronellol positively impacts the cider's olfactory qualities [60] through its citrus, fresh, and floral aromas [90]. Although there is limited information relating to the occurrence of $\alpha$-terpineol in ciders, it is commonly found in muscat wine [91]. This compound is produced through the biotransformation of geraniol and is only detected postfermentation, with its concentration being influenced by the type of yeast used in fermentation [92].

\subsection{Volatile Phenols}

Volatile phenol compounds are of particular interest in ciders due to the distinct and vital roles they play in cider quality, including imparting colour, bitterness, and astringency, whilst also providing health-benefitting properties through their capacity for antioxidative scavenging of free radicals $[93,94]$. In this work, phenols were found to be one of the most diverse groups of compounds.

Tyrosol, a derivative of 2-phenylethanol, formed during fermentation through the deamination of tyrosine [95], was abundant, detected in 12 of the 14 ciders. Tyrosol is notable for influencing the bitterness of wine [96], as well as providing numerous beneficial health effects [97].

The volatile phenols chavicol and eugenol were also detected in 13 and 10 of the 14 ciders, respectively. These volatile phenols contribute sweet, spicy, and clove aromas [5].

Within the volatile phenols, 2-ethylphenol is unique in that its sensory properties are not considered desirable. Described as producing a raw and peppery aroma [98], it has also been associated with flavours such as leather, cow manure, and asphalt in wine [99]. 2-Ethylphenol is produced by the biotransformation of hydroxycinnamic acid and is commonly related to the presence of Lactobacillus collinoides [100], a lactic-acid-producing bacteria involved in the spoilage of cider [101]. Consequently, thermal pasteurisation is often used to remove $L b$. collinoides and improve the quality of ciders. However, Lb. collinoides 
have been shown to develop heat-resistant traits when exposed to less than lethal levels of heat [102]; additionally, pasteurisation can diminish favourable organoleptic and nutritional properties in cider [103]. Other methods, such as microfiltration and UV treatment, have been successfully used to remove Escherichia coli, Cryptosporidium parvum, and Alicyclobacillus acidoterrestris from cider [103]. Further research is required to assess the application of these methods to reduce $L b$. collinoides, and the potential to reduce undesirable properties within cider.

\subsection{Ketones}

6-Methyl-5-hepten-2-one (MHO) was the only detected ketone that plays an important role in overall cider quality, described as providing an apple-like scent [104]. MHO is likely produced from the oxidative decomposition of $\alpha$-farnesene, a volatile sesquiterpene, during fruit postharvest storage [104]. Additionally, the production and accumulation of $\mathrm{MHO}$ have been connected to the fruit postharvest storage temperature, with a rapid increase in $\mathrm{MHO}$ production detected in fruit stored at $20^{\circ} \mathrm{C}$ for $6 \mathrm{~h} \mathrm{[105].}$

Whilst diacetone alcohol was found in three of the ciders analyzed, this compound appeared to be absent from the reviewed literature. The use of diacetone alcohol within flavor enhancer products is one plausible explanation for its presence within these ciders [106].

Interestingly, 3-hexen-2-one was also found in all the cider samples, comprising between 5 and $11 \%$ of the VOC composition. There is currently no literature indicating the presence of 3-hexen-2-one as a common VOC in ciders or apples; however, it is a major component of the seeds from the camphor tree, Cinnamomum camphora [107]. Further investigation into the source of this compound in the cider samples is required.

\subsection{Ethers}

1,4-Diethoxy-2-butene, which was found at trace level in all of the ciders analyzed, is commonly found in the leaves of the Acacia auriculiformis (black wattle) [108]. Again, further exploration of the source of this compound in the cider samples is required.

\subsection{Furans}

Furfural has minimal effect on the aroma profile in wine and has been described as a toxin towards S. cerevisiae [109]. This deleterious function on yeast has been studied as a tool for inhibiting the alcohol production of wine during fermentation [110]. The occurrence of furfural in cider is often attributed to storage conditions, as studies have shown that furfural is connected to the use of oak wood barrels, particularly in instances where charring or toasting is involved [111]. Ciders 1 and 6 contained trace levels of furfural, possibly indicating some form of interaction with oak components during post-fermentation. However, as limited information was available on the manufacturing processes of the ciders, this could not be confirmed.

Coumarin was found in 12 of the ciders analyzed and has previously been identified as a VOC from wines and spirits which have been wood aged [112]. However, there is no indication that coumarin provides any noticeable aroma or flavor properties [113,114].

\subsection{Acetal}

The occurrence of diethyl acetal has been linked to oxygenation potential during fermentation, which is expected to improve the cider's aroma qualities [115]. Diethyl acetal was detected to be present in abundance in all ciders analyzed, with relative presence ranging from $4-14 \%$. It is likely that all ciders would have undergone oxygenation processes during fermentation. Further research would be able to indicate whether the increase of diethyl acetal responds linearly to increasing degrees of oxygenation, potentially providing a means to assess current methods and improve cider quality. 


\subsection{Aldehydes}

Aldehydes are described as constituting an herbaceous or solvent-like aroma, and are a minor component of ciders' volatile profile. Work conducted and reported by Liu, et al. [116] indicates that the fermentation process considerably reduces the concentration of several aldehydes (including benzaldehyde) compared to their respective unfermented fruit juice.

Whilst benzaldehyde is not commonly found in ciders, its presence has been shown to be connected to the process of pasteurization [117]. Despite this, benzaldehyde was detected in cider 6, whilst the other ciders from the same manufacturer showed no presence of benzaldehyde. This can be attributed to benzaldehyde being a common compound found in passionfruit juice [118], and that cider 6 was passionfruit flavored, uniquely so amongst the ciders analyzed in this work.

\subsection{Chemometric Analysis}

The principal component analysis performed on the volatile dataset showed acceptable levels of variable reduction, with principal components 1 and 2 explaining $24 \%$ and $20 \%$ of the variability, respectively. Notably, the scores plot of PC-1 and PC-2 demonstrated good separation of the ciders by the manufacturer (Figure 2), indicating a characteristic overall volatile composition for ciders from the same manufacturer. If a suitably large database was compiled of the volatile composition of ciders from a large number of manufacturers, this information could potentially be used for authentication purposes, i.e., confirming whether a cider was produced by the company stated on the label.



Figure 2. Scores plot showing the results of principal component analysis performed on the normalized volatile data.

The loadings plot for the PCA (Figure 3) demonstrated that many of the VOCs identified played a role in the separation by manufacturer. Compounds such as diacetone alcohol, 3-hexen-2-one and 3-methoxy-1-butanol were positively loaded on PC-1, while hexanoic acid, butanoic acid, and pentyl acetate were negatively loaded. 


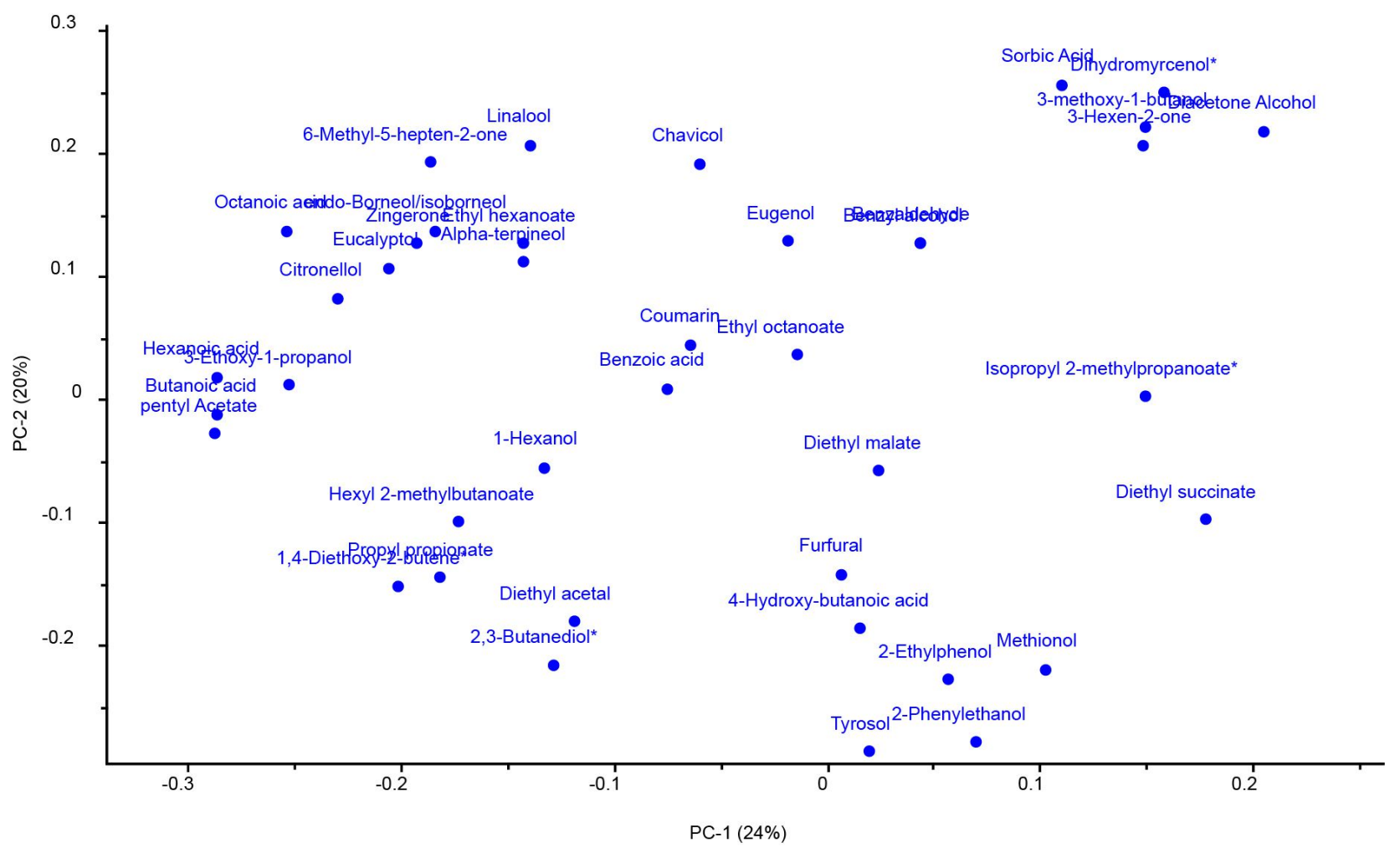

Figure 3. Loadings plot for the principal component analysis.

The second principal component (PC-2) showed stronger loadings of the VOCs found in higher concentrations, with both 2-phenylethanol and tyrosol negatively loading on this PC, while chavicol, eugenol, and linalool were positively loaded on PC-2. Although Manufacturer A only produces cider 1, this cider formed a group with cider 2, which is also listed as a "medium-dry" cider. The location of these ciders showed neutral PC-1 and negative PC-2 loading, correlating with higher tyrosol and 2-phenelethanol concentrations.

Manufacturer B formed a group with positive loadings on PC-1 and negative loadings on PC-2. Ciders 4 and 14 are both bottle fermented, which is a process first introduced in champagne production; sugar and yeast is added to the already fermented cider to increase alcohol content and to provide carbonation. Cider 3 is described as a "wine-like" cider, with no clear indication of being bottle fermented. However, all three ciders are associated with higher levels of diethyl succinate, as indicated by the location of this compound on the loadings plot (Figure 3). Diethyl succinate is known to decrease in concentration as a result of venting during maturation of cider spirits [25], indicating that it is possible that all three of these ciders were sealed immediately post-fermentation, or underwent bottle fermentation.

Manufacturer $C$ showed good separation from the other manufacturers, with positive loadings on both PC-1 and PC-2, indicating that sorbic acid, dihydromyrcenol, 3-methoxy1-butanol, diacetone alcohol, and 3-hexen-2-one are predominant in ciders made by that manufacturer. The strong grouping of the ciders 5-9 indicates that the materials and production of these five different cider flavors are quite similar. This result provides a strong indication that, given sufficient sample sizes, this method of volatile analysis combined with chemometric data analysis could be used for brand identification, allowing for the authentication of cider products.

Manufacturer D consisted of ciders 10-13, with three of these ciders forming a group negatively loaded on both PC-1 and PC-2. Compounds associated with this loading region include hexyl 2-methylbutanoate, which is strongly associated with Pink Lady apples [18]. This suggests that Manufacturer D may use Pink Lady apples at a higher concentration compared to other manufacturers. However, as the apple variety was not specified by most 
cider manufacturers, this hypothesis could not be investigated further. Additionally, the PCA indicated that 1-hexanol is more abundant in ciders from Manufacturer D; previously suggested methods of reducing 1-hexanol levels could be of use for improving the quality of ciders 11-13. Lastly, cider 10 is somewhat of an outlier, with a strongly negative loading on PC-1 and a positive loading on PC-2. This is likely due to the influence of compounds such as eucalyptol and zingerone, both of which were correlated with this region of the PCA (see Figure 3).

In order to further investigate the similarities and differences between the various cider samples, hierarchical cluster analysis was also performed on the VOC dataset. As previously mentioned, this method of data analysis attempts to identify "clusters" of samples with similar composition to one another.

The dendrogram created with the results of hierarchical cluster analysis broadly supported the separation by manufacturer observed in the PCA, but also provided further insight into the similarities of VOC composition between ciders of different manufacturers. In this instance, the "relative distance" on the $x$-axis of Figure 4 indicates the degree of difference between VOC compositions, with a shorter distance indicating greater similarity. The ciders from manufacturer $C$ formed a separate cluster on the dendrogram (Figure 4), indicating their composition was extremely distinct from the ciders of these remaining three manufacturers. Within this cluster, it is observed that the ciders could be separated into two distinct groups. One group included the plain apple ciders $(7,8$, and 9), all of which contained hexyl 2-methylbutonate (Table 3), which is associated with Pink Lady apples [18]. The ciders within the other group (5 and 6) do not contain hexyl 2-methylbutonate. However, both of these ciders contained more diverse monoterpene and volatile phenol profiles (Table 3), likely due to added ingredients, such as orange/ginger (cider 5) and passionfruit (cider 6).

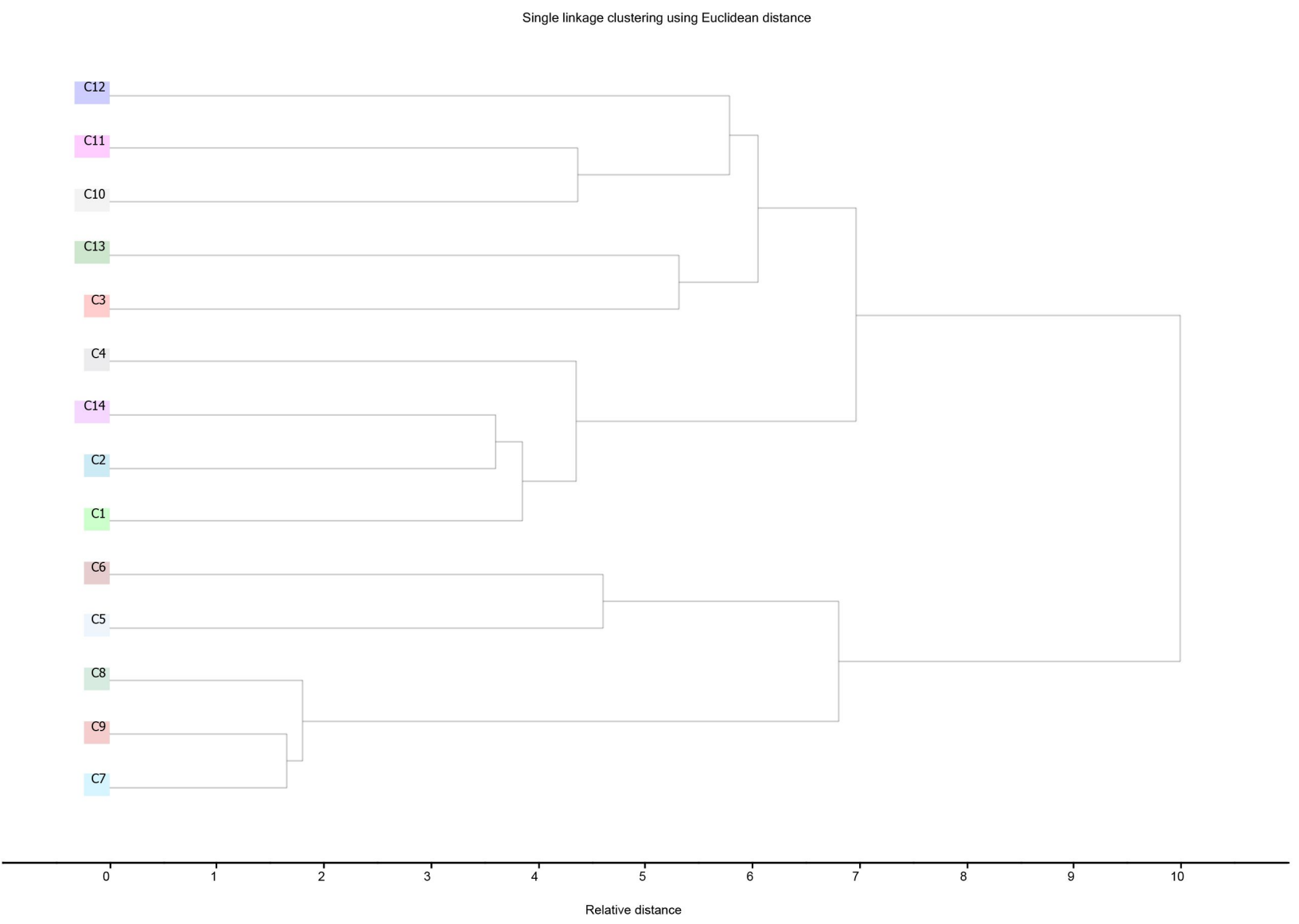

Figure 4. Dendrogram showing the results of hierarchical cluster analysis performed on the normalized volatile data. 
The other "leg" of the dendrogram was separated into a further two major clustersone comprising three ciders from Manufacturer B and the one cider from Manufacturer A, while the second cluster comprised ciders from Manufacturer D, and one cider from Manufacturer B.

The middle cluster on the dendrogram included ciders 1,2,4, and 14. The similarity of 1 and 2 was expected, as both ciders are described as "medium-dry" on the label, although they are produced by different manufacturers. Ciders 4 and 14 were both bottle fermented, and all four of the ciders in this cluster contain relatively high levels of tyrosol (Table 3), known for its contribution to wine bitterness [96]. It is worth noting that 3 also contained high levels of tyrosol; however, its low levels of 2-phenylethanol shifted its similarity towards that of the ciders in the upper cluster.

The upper cluster of the dendrogram contains two predominant groups, the first group, which included ciders 10,11, and 12, includes ciders with added ginger, shiraz wine, and Pink Lady apples. These ciders include three of the four ciders that contained butanoic acid and contained high levels of octanoic acid (Table 3), two compounds that are both associated with unpleasant cheesy odors. Cider 13 contains similar concentrations of octanoic acid, but butanoic acid at much lower concentrations. However, cider 13 also contains diethyl malate and 2-ethylphenol at concentrations similar to cider 3 (Table 3), both of which are positioned almost neutral on PC-1 and negatively on PC-2 (Figure 3), which place them in the middle of the groups for Manufacturer B and D (Figure 2).

\section{Conclusions}

The aim of this study was to profile the VOC composition of 14 commercial Queensland ciders, including a proof-of-concept demonstration of a statistical method which could be utilized in discriminating ciders by their manufacturer. The clustering of ciders by manufacturer provides valuable insight into the distinct VOC profile of each manufacturer, but also the compounds which are shared between manufacturers. However, it is important to note that this study only considered ciders from one region of Australia (Queensland). Increasing the number of different manufacturer locations and the number of ciders analyzed would be required to increase the confidence of future applications. As a proof-of-concept study, our results give credence to the prospect of using the VOC composition of ciders for discriminating between ciders from different manufacturers or confirming the manufacturing process/ingredients used to make the cider. In turn, this could be useful for identifying ciders which have been adulterated, or products which are being falsely sold as ciders (e.g., cider-like alcopops). Furthermore, this work builds towards developing a library of data which can be used to connect certain ingredients or manufacturing processes to specific compounds and properties of the cider. This information can then be used to guide the targeted modification of ciders' volatile profiles for the improvement of the final product.

Author Contributions: Conceptualization, A.W., J.B.J., and M.N.; data curation, A.W.; formal analysis, A.W. and J.B.J.; funding acquisition, M.N.; investigation, A.W.; methodology, A.W.; project administration, A.W. and M.N.; resources, M.N.; software, J.B.J.; supervision, M.N.; visualization, J.B.J.; writing—original draft, A.W.; writing—review and editing, A.W., J.B.J., R.B., P.L., L.W., and M.N. All authors have read and agreed to the published version of the manuscript.

Funding: This work was supported in part by a New Staff Grant (RSH/5343) awarded by CQUniversity to one of the authors (M.N.).

Data Availability Statement: Data are available from the authors upon request.

Acknowledgments: The authors gratefully acknowledge the assistance of Tania Collins in completing the laboratory work. Additionally, the authors gratefully acknowledge Witches Falls Winery and Sunshine Coast Cider for their cider donations for analysis in this project.

Conflicts of Interest: The authors declare no conflict of interest. 


\section{References}

1. Allen, M. The Australian Cider Guide. Available online: http://www.cideraustralia.org.au/the-australian-cider-guide/ (accessed on 7 January 2021).

2. Australian Bereau of Statistics. Apparent Consumption of Alcohol, Australia. Available online: https://www.abs.gov. $\mathrm{au} /$ statistics/health/health-conditions-and-risks/apparent-consumption-alcohol-australia/latest-release (accessed on 7 January 2021).

3. Cider Australia. Trust Mark. Available online: http://www.cideraustralia.org.au/trustmark/ (accessed on 7 January 2021).

4. Rosend, J.; Kuldjärv, R.; Rosenvald, S.; Paalme, T. The effects of apple variety, ripening stage, and yeast strain on the volatile composition of apple cider. Heliyon 2019, 5, e01953. [CrossRef] [PubMed]

5. Xu, Y.; Fan, W.; Qian, M.C. Characterization of aroma compounds in apple cider using solvent-assisted flavor evaporation and headspace solid-phase microextraction. J. Agric. Food Chem. 2007, 55, 3051-3057. [CrossRef] [PubMed]

6. Mendes, B.; Gonçalves, J.; Câmara, J.S. Effectiveness of high-throughput miniaturized sorbent-and solid phase microextraction techniques combined with gas chromatography-mass spectrometry analysis for a rapid screening of volatile and semi-volatile composition of wines-A comparative study. Talanta 2012, 88, 79-94. [CrossRef]

7. Perestrelo, R.; Silva, C.L.; Silva, P.; Medina, S.; Pereira, R.; Camara, J.S. Untargeted fingerprinting of cider volatiles from different geographical regions by HS-SPME/GC-MS. Microchem. J. 2019, 148, 643-651. [CrossRef]

8. Poll, L. Influence of storage temperature on sensory evaluation and composition of volatiles of McIntosh apple juice. LWT 1983, 16, 220-223.

9. Poll, L. The influence of apple ripeness and juice storage temperature on the sensory evaluation and composition (volatile and non-volatile components) of apple juice. Lebensm. Wiss. Technol. 1985, 18, 205-211.

10. Cunningham, D.; Acree, T.; Barnard, J.; Butts, R.M.; Braell, P. Charm analysis of apple volatiles. Food Chem. 1986, 19, 137-147. [CrossRef]

11. Petró-Turza, M.; Szarfoldi-Szalma, I.; Madarassy-Mersich, E.; Teleky-Vámossy, G.; Fuzesi-Kardos, K. Correlation between chemical composition and sensory quality of natural apple aroma condensates. Die Nahr. Food 1986, 30, 765.

12. Young, H.; Gilbert, J.M.; Murray, S.H.; Ball, R.D. Causal effects of aroma compounds on Royal Gala apple flavours. J. Sci. Food Agric. 1996, 71, 329-336. [CrossRef]

13. López, M.; Lavilla, M.; Riba, M.; Vendrell, M. Comparison of volatile compounds in two seasons in apples: Golden Delicious and Granny Smith. J. Food Qual. 1998, 21, 155-166. [CrossRef]

14. Lorenzini, M.; Simonato, B.; Slaghenaufi, D.; Ugliano, M.; Zapparoli, G. Assessment of yeasts for apple juice fermentation and production of cider volatile compounds. LWT 2019, 99, 224-230. [CrossRef]

15. Ye, M.; Yue, T.; Yuan, Y. Changes in the profile of volatile compounds and amino acids during cider fermentation using dessert variety of apples. Eur. Food Res. Technol. 2014, 239, 67-77. [CrossRef]

16. Kakiuchi, N.; Moriguchi, S.; Fukuda, H.; Ichimura, N.; Kato, Y.; Banba, Y. Composition of volatile compounds of apple fruits in relation to cultivars. J. Jpn. Soc. Hortic. Sci. 1986, 55, 280-289. [CrossRef]

17. Holland, D.; Larkov, O.; Bar-Ya'akov, I.; Bar, E.; Zax, A.; Brandeis, E.; Ravid, U.; Lewinsohn, E. Developmental and varietal differences in volatile ester formation and acetyl-CoA: Alcohol acetyl transferase activities in apple (Malus domestica Borkh.) fruit. J. Agric. Food Chem. 2005, 53, 7198-7203. [CrossRef]

18. Villatoro, C.; Luisa López, M.; Echeverria, G.; Graell, J. Effect of controlled atmospheres and shelf life period on concentrations of volatile substances released by 'Pink Lady®'apples and on consumer acceptance. J. Sci. Food Agric. 2009, 89, 1023-1034. [CrossRef]

19. Medina, S.; Perestrelo, R.; Pereira, R.; Câmara, J.S. Evaluation of Volatilomic Fingerprint from Apple Fruits to Ciders: A Useful Tool to Find Putative Biomarkers for Each Apple Variety. Foods 2020, 9, 1830. [CrossRef]

20. Nešpor, J.; Karabín, M.; Štulíková, K.; Dostálek, P. An HS-SPME-GC-MS Method for Profiling Volatile Compounds as Related to Technology Used in Cider Production. Molecules 2019, 24, 2117. [CrossRef]

21. Villière, A.; Arvisenet, G.; Bauduin, R.; Le Quéré, J.M.; Sérot, T. Influence of cider-making process parameters on the odourant volatile composition of hard ciders. J. Inst. Brew. 2015, 121, 95-105. [CrossRef]

22. He, W.; Liu, S.; Heponiemi, P.; Heinonen, M.; Marsol-Vall, A.; Ma, X.; Yang, B.; Laaksonen, O. Effect of Saccharomyces cerevisiae and Schizosaccharomyces pombe strains on chemical composition and sensory quality of ciders made from Finnish apple cultivars. Food Chem. 2021, 345, 128833. [CrossRef]

23. Nogueira, A.; Mongruel, C.; Simões, D.R.S.; Waszczynskyj, N.; Wosiacki, G. Effect of biomass reduction on the fermentation of cider. Braz. Arch. Biol. Technol. 2007, 50, 1083-1092. [CrossRef]

24. Rodríguez Madrera, R.; Picinelli Lobo, A.; Mangas Alonso, J.J. Effect of cider maturation on the chemical and sensory characteristics of fresh cider spirits. Food Res. Int. 2010, 43, 70-78. [CrossRef]

25. Rodríguez Madrera, R.; Suárez Valles, B.; Picinelli Lobo, A. Chemical and sensory changes in fresh cider spirits during maturation in inert containers. J. Sci. Food Agric. 2011, 91, 797-804. [CrossRef] [PubMed]

26. van Den Dool, H.; Kratz, P.D. A generalization of the retention index system including linear temperature programmed gas-liquid partition chromatography. J. Chromatogr. A 1963, 11, 463-471. [CrossRef]

27. Cozzolino, D.; Power, A.; Chapman, J. Interpreting and reporting principal component analysis in food science analysis and beyond. Food Anal. Methods 2019, 12, 2469-2473. [CrossRef] 
28. Echeverría, G.; Graell, J.; Lara, I.; López, M. Physicochemical measurements in ‘Mondial Gala®’apples stored at different atmospheres: Influence on consumer acceptability. Postharvest Biol. Technol. 2008, 50, 135-144. [CrossRef]

29. Echeverrıa, G.; Fuentes, T.; Graell, J.; Lara, I.; López, M. Aroma volatile compounds of 'Fuji'apples in relation to harvest date and cold storage technology: A comparison of two seasons. Postharvest Biol. Technol. 2004, 32, 29-44. [CrossRef]

30. Guo, J.; Yue, T.; Yuan, Y.; Sun, N.; Liu, P. Characterization of volatile and sensory profiles of apple juices to trace fruit origins and investigation of the relationship between the aroma properties and volatile constituents. LWT 2020, 124, 109203. [CrossRef]

31. National Center for Biotechnology Information. Propyl Propionate. Available online: https://pubchem.ncbi.nlm.nih.gov/ compound/7803 (accessed on 17 February 2021).

32. Simpson, R.F. Volatile aroma components of Australian port wines. J. Sci. Food Agric. 1980, 31, 214-222. [CrossRef]

33. Saerens, S.; Delvaux, F.; Verstrepen, K.; Van Dijck, P.; Thevelein, J.; Delvaux, F. Parameters affecting ethyl ester production by Saccharomyces cerevisiae during fermentation. Appl. Environ. Microbiol. 2008, 74, 454-461. [CrossRef]

34. Nicolini, G.; Román, T.; Carlin, S.; Malacarne, M.; Nardin, T.; Bertoldi, D.; Larcher, R. Characterisation of single-variety still ciders produced with dessert apples in the Italian Alps. J. Inst. Brew. 2018, 124, 457-466. [CrossRef]

35. Esteban-Decloux, M.; Dechatre, J.-C.; Legendre, P.; Guichard, H. Double batch cider distillation: Influence of the recycling of the separated fractions. LWT 2021, 146, 111420. [CrossRef]

36. Mangwanda, T.; Johnson, J.B.; Mani, J.S.; Jackson, S.; Chandra, S.; McKeown, T.; White, S.; Naiker, M. Processes, Challenges and Optimisation of Rum Production from Molasses-A Contemporary Review. Fermentation 2021, 7, 21. [CrossRef]

37. Villière, A.; Arvisenet, G.; Lethuaut, L.; Prost, C.; Sérot, T. Selection of a representative extraction method for the analysis of odourant volatile composition of French cider by GC-MS-O and GC $\times$ GC-TOF-MS. Food Chem. 2012, 131, 1561-1568. [CrossRef]

38. Jordán, M.J.; Margaría, C.A.; Shaw, P.E.; Goodner, K.L. Volatile components and aroma active compounds in aqueous essence and fresh pink guava fruit puree (Psidium guajava L.) by GC-MS and multidimensional GC/GC-O. J. Agric. Food Chem. 2003, 51, 1421-1426. [CrossRef]

39. Adams, R.P. Identification of Essential Oil Components by Gas Chromatography/Mass Spectrometry; Allured Publishing Corporation: Carol Stream, IL, USA, 2007; Volume 456.

40. Chastrette, M.; Heintz, M.; Druilhe, A.; Lefort, D. Analyse chromatographique d'esters aliphatiques saturés. Relations rétentionstructure et prévision de la rétention. Bull. Soc. Chim. Fr. 1974, 375, 1852-1856.

41. Fan, S.; Chang, J.; Zong, Y.; Hu, G.; Jia, J. GC-MS analysis of the composition of the essential oil from Dendranthema indicum Var. Aromaticum using three extraction methods and two columns. Molecules 2018, 23, 576. [CrossRef]

42. Liu, Y.; Xu, X.l.; Zhou, G.h. Comparative study of volatile compounds in traditional Chinese Nanjing marinated duck by different extraction techniques. Int. J. Food Sci. Technol. 2007, 42, 543-550. [CrossRef]

43. Rychlik, M.; Schieberle, P.; Grosch, W. Compilation of Odor Thresholds, Odor Qualities and Retention Indices of Key Food Odorants; Technische Universität München: Munich, Germany, 1998; pp. 1-63.

44. Mevy, J.-P.; Bessiere, J.-M.; Greff, S.; Zombre, G.; Viano, J. Composition of the volatile oil from the leaves of Ximenia americana L. Biochem. Syst. Ecol. 2006, 34, 549-553. [CrossRef]

45. Jordan, M.J.; Margaria, C.A.; Shaw, P.E.; Goodner, K.L. Aroma active components in aqueous kiwi fruit essence and kiwi fruit puree by GC-MS and multidimensional GC/GC-O. J. Agric. Food Chem. 2002, 50, 5386-5390. [CrossRef]

46. El-Sayed, A.; Heppelthwaite, V.; Manning, L.; Gibb, A.; Suckling, D. Volatile constituents of fermented sugar baits and their attraction to lepidopteran species. J. Agric. Food Chem. 2005, 53, 953-958. [CrossRef]

47. Bruna, J.M.; Hierro, E.M.; de la Hoz, L.; Mottram, D.S.; Fernández, M.; Ordóñez, J.A. Changes in selected biochemical and sensory parameters as affected by the superficial inoculation of Penicillium camemberti on dry fermented sausages. Int. J. Food Microbiol. 2003, 85, 111-125. [CrossRef]

48. Machiels, D.; Van Ruth, S.M.; Posthumus, M.A.; Istasse, L. Gas chromatography-olfactometry analysis of the volatile compounds of two commercial Irish beef meats. Talanta 2003, 60, 755-764. [CrossRef]

49. Qian, M.; Reineccius, G. Potent aroma compounds in Parmigiano Reggiano cheese studied using a dynamic headspace (purgetrap) method. Flavour Fragr. J. 2003, 18, 252-259. [CrossRef]

50. Choi, H.-S. Character impact odorants of Citrus Hallabong [(C. unshiu Marcov $\times$ C. sinensis Osbeck $) \times$ C. reticulata Blanco] cold-pressed peel oil. J. Agric. Food Chem. 2003, 51, 2687-2692. [CrossRef]

51. Pino, J.; Marbot, R.; Rosado, A. Volatile constituents of star apple (Chrysophyllum cainito L.) from Cuba. Flavour Fragr. J. 2002, 17, 401-403. [CrossRef]

52. da Silva, M.H.L.; Andrade, E.H.A.; Zoghbi, M.d.G.B.; Luz, A.I.R.; da Silva, J.D.; Maia, J.G.S. The essential oils of Lantana camara L. occurring in North Brazil. Flavour Fragr. J. 1999, 14, 208-210. [CrossRef]

53. Lalel, H.J.; Singh, Z.; Tan, S.C. Glycosidically-bound aroma volatile compounds in the skin and pulp of 'Kensington Pride'mango fruit at different stages of maturity. Postharvest Biol. Technol. 2003, 29, 205-218. [CrossRef]

54. Vidrih, R.; Hribar, J. Synthesis of higher alcohols during cider processing. Food Chem. 1999, 67, 287-294. [CrossRef]

55. Bingman, M.T.; Stellick, C.E.; Pelkey, J.P.; Scott, J.M.; Cole, C.A. Monitoring Cider Aroma Development throughout the Fermentation Process by Headspace Solid Phase Microextraction (HS-SPME) Gas Chromatography-Mass Spectrometry (GC-MS) Analysis. Beverages 2020, 6, 40. [CrossRef]

56. Azhu Valappil, Z.; Fan, X.; Zhang, H.Q.; Rouseff, R.L. Impact of thermal and nonthermal processing technologies on unfermented apple cider aroma volatiles. J. Agric. Food Chem. 2009, 57, 924-929. [CrossRef] [PubMed] 
57. Hubert, B.; Baron, A.; Le Quere, J.-M.; Renard, C.M. Influence of prefermentary clarification on the composition of apple musts. J. Agric. Food Chem. 2007, 55, 5118-5122. [CrossRef] [PubMed]

58. Beech, F.; Carr, J. Cider and perry. Alcohol. Beverages 1977, 1, 139-313.

59. Mei, J.; Min, H.; Lü, Z. Enhanced biotransformation of L-phenylalanine to 2-phenylethanol using an in situ product adsorption technique. Process Biochem. 2009, 44, 886-890. [CrossRef]

60. Fan, W.; Xu, Y.; Han, Y. Quantification of volatile compounds in Chinese ciders by stir bar sorptive extraction (SBSE) and gas chromatography-mass spectrometry (GC-MS). J. Inst. Brew. 2011, 117, 61-66. [CrossRef]

61. Garde-Cerdán, T.; Ancín-Azpilicueta, C. Effect of the addition of different quantities of amino acids to nitrogen-deficient must on the formation of esters, alcohols, and acids during wine alcoholic fermentation. Lwt Food Sci. Technol. 2008, 41, 501-510. [CrossRef]

62. Etschmann, M.; Schrader, J. An aqueous-organic two-phase bioprocess for efficient production of the natural aroma chemicals 2-phenylethanol and 2-phenylethylacetate with yeast. Appl. Microbiol. Biotechnol. 2006, 71, 440-443. [CrossRef]

63. Qin, Z.; Petersen, M.A.; Bredie, W.L. Flavor profiling of apple ciders from the UK and Scandinavian region. Food Res. Int. 2018, 105, 713-723. [CrossRef]

64. Bult, J.H.; Schifferstein, H.N.; Roozen, J.P.; Boronat, E.D.; Voragen, A.G.; Kroeze, J.H. Sensory evaluation of character impact components in an apple model mixture. Chem. Senses 2002, 27, 485-494. [CrossRef]

65. Eleutério dos Santos, C.M.; Pietrowski, G.d.A.M.; Braga, C.M.; Rossi, M.J.; Ninow, J.; Machado dos Santos, T.P.; Wosiacki, G.; Jorge, R.M.M.; Nogueira, A. Apple aminoacid profile and yeast strains in the formation of fusel alcohols and esters in cider production. J. Food Sci. 2015, 80, C1170-C1177. [CrossRef]

66. Dennis, E.G.; Keyzers, R.A.; Kalua, C.M.; Maffei, S.M.; Nicholson, E.L.; Boss, P.K. Grape contribution to wine aroma: Production of hexyl acetate, octyl acetate, and benzyl acetate during yeast fermentation is dependent upon precursors in the must. J. Agric. Food Chem. 2012, 60, 2638-2646. [CrossRef]

67. Rodríguez Madrera, R.; Suárez Valles, B. Determination of volatile compounds in cider spirits by gas chromatography with direct injection. J. Chromatogr. Sci. 2007, 45, 428-434. [CrossRef]

68. Li, C.X.; Zhao, X.H.; Zuo, W.F.; Zhang, T.L.; Zhang, Z.Y.; Chen, X.S. The effects of simultaneous and sequential inoculation of yeast and autochthonous Oenococcus oeni on the chemical composition of red-fleshed apple cider. LWT 2020, 124, 109184. [CrossRef]

69. Tao, Y.-S.; Li, H. Active volatiles of cabernet sauvignon wine from Changli County. Health 2009, 1, 176. [CrossRef]

70. Rodríguez Madrera, R.; Mangas Alonso, J. Distribution of the principal minor volatiles during cider distillation in 'alquitara'. Acta Aliment. 2011, 40, 262-269. [CrossRef]

71. De Torres, C.; Díaz-Maroto, M.; Hermosín-Gutiérrez, I.; Pérez-Coello, M. Effect of freeze-drying and oven-drying on volatiles and phenolics composition of grape skin. Anal. Chim. Acta 2010, 660, 177-182. [CrossRef]

72. Castro-Vázquez, L.; Leon-Ruiz, V.; Alañon, M.; Pérez-Coello, M.; González-Porto, A. Floral origin markers for authenticating Lavandin honey (Lavandula angustifolia x latifolia). Discrimination from Lavender honey (Lavandula latifolia). Food Control. 2014, 37, 362-370. [CrossRef]

73. Leão, K.M.; Sampaio, K.L.; Pagani, A.A.; Da Silva, M.A.A. Odor potency, aroma profile and volatiles composition of cold pressed oil from industrial passion fruit residues. Ind. Crop. Prod. 2014, 58, 280-286. [CrossRef]

74. Connell, D.; Sutherland, M. A re-examination of gingerol, shogaol, and zingerone, the pungent principles of ginger (Zingiber officinale Roscoe). Aust. J. Chem. 1969, 22, 1033-1043. [CrossRef]

75. Mestres, M.; Busto, O.; Guasch, J. Analysis of organic sulfur compounds in wine aroma. J. Chromatogr. A 2000, 881, 569-581. [CrossRef]

76. Ye, M.; Yue, T.; Yuan, Y. Evolution of polyphenols and organic acids during the fermentation of apple cider. J. Sci. Food Agric. 2014, 94, 2951-2957. [CrossRef]

77. Liu, J.; Liu, M.; Ye, P.; Lin, F.; Huang, J.; Wang, H.; Zhou, R.; Zhang, S.; Zhou, J.; Cai, L. Characterization of major properties and aroma profile of kiwi wine co-cultured by Saccharomyces yeast (S. cerevisiae, S. bayanus, S. uvarum) and T. delbrueckii. Eur. Food Res. Technol. 2020, 246, 807-820. [CrossRef]

78. Wang, X.; Fan, W.; Xu, Y. Comparison on aroma compounds in Chinese soy sauce and strong aroma type liquors by gas chromatography-olfactometry, chemical quantitative and odor activity values analysis. Eur. Food Res. Technol. 2014, 239, 813-825. [CrossRef]

79. Alexandre, H.; Charpentier, C. Biochemical aspects of stuck and sluggish fermentation in grape must. J. Ind. Microbiol. Biotechnol. 1998, 20, 20-27. [CrossRef]

80. Lino, C.; Pena, A. Occurrence of caffeine, saccharin, benzoic acid and sorbic acid in soft drinks and nectars in Portugal and subsequent exposure assessment. Food Chem. 2010, 121, 503-508. [CrossRef]

81. Gutiérrez, A.; Boekhout, T.; Gojkovic, Z.; Katz, M. Evaluation of non-Saccharomyces yeasts in the fermentation of wine, beer and cider for the development of new beverages. J. Inst. Brew. 2018, 124, 389-402. [CrossRef]

82. Capone, D.L.; Van Leeuwen, K.; Taylor, D.K.; Jeffery, D.W.; Pardon, K.H.; Elsey, G.M.; Sefton, M.A. Evolution and occurrence of 1, 8-cineole (Eucalyptol) in Australian wine. J. Agric. Food Chem. 2011, 59, 953-959. [CrossRef]

83. Wei, J.; Wang, S.; Zhang, Y.; Yuan, Y.; Yue, T. Characterization and screening of non-Saccharomyces yeasts used to produce fragrant cider. LWT 2019, 107, 191-198. [CrossRef] 
84. Herve, E.; Price, S.; Burns, G. Eucalyptol in wines showing a "eucalyptus" aroma. In Proceedings of the VIIeme Symp. Internat. d'Oenologie, Actualites Oenologiques, Bordeaux, France, 19-21 June 2003; pp. 19-21.

85. Walia, M.; Mann, T.S.; Kumar, D.; Agnihotri, V.K.; Singh, B. Chemical composition and in vitro cytotoxic activity of essential oil of leaves of Malus domestica growing in Western Himalaya (India). Evid. Based Complementary Altern. Med. 2012, $2012,649727$. [CrossRef]

86. Wohlmuth, H.; Smith, M.K.; Brooks, L.O.; Myers, S.P.; Leach, D.N. Essential oil composition of diploid and tetraploid clones of ginger (Zingiber officinale Roscoe) grown in Australia. J. Agric. Food Chem. 2006, 54, 1414-1419. [CrossRef]

87. Alegre, Y.; Sáenz-Navajas, M.-P.; Ferreira, V.; García, D.; Razquin, I.; Hernández-Orte, P. Rapid strategies for the determination of sensory and chemical differences between a wealth of similar wines. Eur. Food Res. Technol. 2017, 243, 1295-1309. [CrossRef]

88. Hausch, B.J.; Lorjaroenphon, Y.; Cadwallader, K.R. Flavor chemistry of lemon-lime carbonated beverages. J. Agric. Food Chem. 2015, 63, 112-119. [CrossRef]

89. Januszek, M.; Satora, P.; Tarko, T. Oenological characteristics of fermented apple musts and volatile profile of brandies obtained from different apple cultivars. Biomolecules 2020, 10, 853. [CrossRef]

90. Elsharif, S.A.; Buettner, A. Influence of the chemical structure on the odor characters of $\beta$-citronellol and its oxygenated derivatives. Food Chem. 2017, 232, 704-711. [CrossRef]

91. Bordiga, M.; Rinaldi, M.; Locatelli, M.; Piana, G.; Travaglia, F.; Coïsson, J.D.; Arlorio, M. Characterization of Muscat wines aroma evolution using comprehensive gas chromatography followed by a post-analytic approach to 2D contour plots comparison. Food Chem. 2013, 140, 57-67. [CrossRef]

92. Gamero, A.; Manzanares, P.; Querol, A.; Belloch, C. Monoterpene alcohols release and bioconversion by Saccharomyces species and hybrids. Int. J. Food Microbiol. 2011, 145, 92-97. [CrossRef]

93. Frankel, E.N.; Waterhouse, A.L.; Teissedre, P.L. Principal phenolic phytochemicals in selected California wines and their antioxidant activity in inhibiting oxidation of human low-density lipoproteins. J. Agric. Food Chem. 1995, 43, 890-894. [CrossRef]

94. Carbó, N.; Costelli, P.; Baccino, F.M.; López-Soriano, F.J.; Argilés, J.M. Resveratrol, a natural product present in wine, decreases tumour growth in a rat tumour model. Biochem. Biophys. Res. Commun. 1999, 254, 739-743. [CrossRef]

95. Rodríguez Madrera, R.; Picinelli Lobo, A.; Suárez Valles, B. Phenolic profile of Asturian (Spain) natural cider. J. Agric. Food Chem. 2006, 54, 120-124. [CrossRef]

96. Gawel, R.; Smith, P.A.; Cicerale, S.; Keast, R. The mouthfeel of white wine. Crit. Rev. Food Sci. Nutr. 2018, 58, 2939-2956. [CrossRef]

97. Clifford, A.J.; Ebeler, S.E.; Ebeler, J.D.; Bills, N.D.; Hinrichs, S.H.; Teissedre, P.-L.; Waterhouse, A.L. Delayed tumor onset in transgenic mice fed an amino acid-based diet supplemented with red wine solids. Am. J. Clin. Nutr. 1996, 64, 748-756. [CrossRef]

98. Lin, H.; Liu, Y.; He, Q.; Liu, P.; Che, Z.; Wang, X.; Huang, J. Characterization of odor components of Pixian Douban (broad bean paste) by aroma extract dilute analysis and odor activity values. Int. J. Food Prop. 2019, 22, 1223-1234. [CrossRef]

99. Palacios, A.; Suárez, C.; Krieger, S.; Théodore, D.; Otaño, L.; Peña, F. Perception by wine drinkers of sensory defects caused by uncontrolled malolactic fermentation. In Wine Quality and Malolactic Fermentation, Proceedings of the XVIth Entretiens Scientifiques Lallemand, Porto, Portugal, 4-5 May 2004; Lallemand: Montreal, QC, Canada, 2004; pp. 45-52.

100. Antón-Díaz, M.J.; Valles, B.S.; Mangas-Alonso, J.J.; Fernández-García, O.; Picinelli-Lobo, A. Impact of different techniques involving contact with lees on the volatile composition of cider. Food Chem. 2016, 190, 1116-1122. [CrossRef]

101. Claisse, O.; Lonvaud-Funel, A. Assimilation of glycerol by a strain of Lactobacillus collinoides isolated from cider. Food Microbiol. 2000, 17, 513-519. [CrossRef]

102. Laplace, J.; Sauvageot, N.; Hartke, A.; Auffray, Y. Characterization of Lactobacillus collinoides response to heat, acid and ethanol treatments. Appl. Microbiol. Biotechnol. 1999, 51, 659-663. [CrossRef]

103. Zhao, D.; Barrientos, J.U.; Wang, Q.; Markland, S.M.; Churey, J.J.; Padilla-Zakour, O.I.; Worobo, R.W.; Kniel, K.E.; Moraru, C.I. Efficient reduction of pathogenic and spoilage microorganisms from apple cider by combining microfiltration with UV treatment. J. Food Prot. 2015, 78, 716-722. [CrossRef]

104. Versini, G.; Franco, M.A.; Moser, S.; Barchetti, P.; Manca, G. Characterisation of apple distillates from native varieties of Sardinia island and comparison with other Italian products. Food Chem. 2009, 113, 1176-1183. [CrossRef]

105. Whitaker, B.D.; Saftner, R.A. Temperature-dependent autoxidation of conjugated trienols from apple peel yields 6-methyl-5hepten-2-one, a volatile implicated in induction of scald. J. Agric. Food Chem. 2000, 48, 2040-2043. [CrossRef]

106. National Center for Biotechnology Information. Diacetone Alcohol. Available online: https://pubchem.ncbi.nlm.nih.gov/ compound/Diacetone-alcohol (accessed on 9 March 2021).

107. Yong, Y.; Wenyi, T. Head-space solid phase micro-extraction followed by GC/MS analysis of the volatile components in seeds of Cinnamonum camphora. Am. J. Biochem. Biotechnol. 2005, 1, 173-175. [CrossRef]

108. Ibrahim, H.; Nwanya, K.; Ayilara, S.; Adegbola, O.; Nwakuba, D.; Tyoor, A.; Ba'are, A.; Shuaibu, H. Potential of earleaf acacia (Acacia auriculiformis) leaves for industrial raw materials. Int. J. Sci. Eng. Appl. Sci. 2015, 1, 462-467.

109. Allen, S.A.; Clark, W.; McCaffery, J.M.; Cai, Z.; Lanctot, A.; Slininger, P.J.; Liu, Z.L.; Gorsich, S.W. Furfural induces reactive oxygen species accumulation and cellular damage in Saccharomyces cerevisiae. Biotechnol. Biofuels 2010, 3, 1-10. [CrossRef] [PubMed]

110. Abalos, D.; Vejarano, R.; Morata, A.; González, C.; Suárez-Lepe, J.A. The use of furfural as a metabolic inhibitor for reducing the alcohol content of model wines. Eur. Food Res. Technol. 2011, 232, 663-669. [CrossRef] 
111. Rodríguez Madrera, R.; Blanco Gomis, D.; Mangas Alonso, J.J. Influence of distillation system, oak wood type, and aging time on composition of cider brandy in phenolic and furanic compounds. J. Agric. Food Chem. 2003, 51, 7969-7973. [CrossRef] [PubMed]

112. Ho, P.; Hogg, T.; Silva, M. Application of a liquid chromatographic method for the determination of phenolic compounds and furans in fortified wines. Food Chem. 1999, 64, 115-122. [CrossRef]

113. Rusu, E.; Obadă, L.; Dumanova, V.; Cibuc, M. Aromatic compounds of wine obtained from the new variety of domestic selection Viorica. In Proceedings of the Modern Technologies in the Food Industry, Chișinău, Moldova, 1-3 November 2012; pp. 115-120.

114. Ugliano, M.; Moio, L. Free and hydrolytically released volatile compounds of Vitis vinifera L. cv. Fiano grapes as odour-active constituents of Fiano wine. Anal. Chim. Acta 2008, 621, 79-85. [CrossRef]

115. Tarko, T.; Duda-Chodak, A.; Sroka, P.; Januszek, M. Effect of Musts Oxygenation at Various Stages of Cider Production on Oenological Parameters, Antioxidant Activity, and Profile of Volatile Cider Compounds. Biomolecules 2020, 10, 890. [CrossRef]

116. Liu, S.; Laaksonen, O.; Yang, B. Volatile composition of bilberry wines fermented with non-Saccharomyces and Saccharomyces yeasts in pure, sequential and simultaneous inoculations. Food Microbiol. 2019, 80, 25-39. [CrossRef]

117. Deot, P. Presence and Growth of Microorganisms in Iowa Apple Cider. Master's Thesis, Iowa State University, Ames, Iowa, 2003.

118. Janzantti, N.S.; Monteiro, M. Changes in the aroma of organic passion fruit (Passiflora edulis Sims f. flavicarpa Deg.) during ripeness. Lwt Food Sci. Technol. 2014, 59, 612-620. [CrossRef] 